\title{
MONOTHEISME RADIKAL: Telaah atas Pemikiran Nurcholish Madjid
}

\section{Didik Lutfi Hakim}

\author{
Universitas Islam As-Syafi'iyah Jakarta \\ e-mail: lutfi_hakim@yahoo.com
}

\begin{abstract}
Nurcholish Madjid is a Muslim intellectual of Indonesia who has given contribution toward Islamic thinking in Indonesia. Although his thoughts of Islam to be critiqued from other intellectual, he stayed to give enlightenment to Indonesia Muslim society. One of his thought is important about radical monotheism. By it, he offered to Islam umma to adhere pure monotheism in God in order to they will free from tyranny which come from the same human and place man in the same line as it is God Willing. By his concept, the tauhid produces social dimensions like equality, freedom, cooperation, and discussion.
\end{abstract}

\begin{abstract}
Abstrak: Nurcholish madjid adalah seorang cendekiawan Muslim Indonesia yang semasa hidupnya, telah banyak memberikan sumbangan pemikiran tentang Islam di Indonesia. Walaupun pemikiran-pemikirannya tentang Islam banyak mendapat kritikan dari para cendekiawan yang tidak seide dengannya, ia tetap saja berupaya melakukan pencerahan terhadap masyarakat Muslim Indonesia. Salah satu pemikirannya yang sangat menonjol adalah tentang monotheisme radikal. Dia menawarkan agar umat Islam bertauhid yang semurni-murninya kepada Tuhan, sehingga ia terbebas dari berbagai macam tirani yang datang dari sesama manusia dan memposisikan manusia harkat dan martabat yang sama sebagaimana yang dikehendaki Tuhan.Dengan konsepnya ini, tauhid menghasilkan dimensi-dimensi sosial seperti persamaan, kebebasan, saling bekerja sama, dan bermusyawarah.
\end{abstract}


Keywords: tauhid, monotheisme radikal, kebebasan, persamaan.

\section{A. Pendahuluan}

Tidak diragukan lagi bahwa salah satu kontribusi yang ditinggalkan oleh Nurcholish Madjid dalam pemikiran Islam di Indonesia adalah konsep tauhid radikal (radical monotheism)-nya. Tauhid dalam pandangan para pembaharu mempunyai fungsi ganda, ibarat pisau bermata dua. Tauhid berarti beriman kepada Allah, Khāliq Yang Satu, sekaligus berarti pengakuan akan prinsip bahwa umat manusia "satu keluarga", "satu persaudaraan" yang anggotaanggota tanpa kecuali sama-sama berhak hidup, terdiri dari unsurunsur fitrah yang sejenis, sama-sama mempunyai martabat kemanusiaan (human dignity). ${ }^{1}$

Dalam al-Quran, misalnya QS. al-Baqarah [2]: 213 menyatakan bahwa manusia diciptakan Allah sebagai umat yang satu, namun kemudian manusia saling berselisih sehingga Dia mengutus para nabi yang bertugas untuk memberikan peringatan. Bersamaan dengan diutusnya para nabi tersebut, Allah menurunkan Kitab yang benar untuk memutuskan mengenai persoalan-persoalan yang diperselisihkan manusia. Perbedaan daerah, bumi tempat mereka diam, perbedaan bahasa dan warna kulit, tidaklah boleh dijadikan alasan untuk berpecah belah. ${ }^{2}$ Karena itu, al-Quran telah meletakkan prinsip keesaan umat manusia. ${ }^{3}$

Bertolak dari prinsip keesaan tersebut, Nurcholish Madjid dianggap sebagai salah satu tokoh pembaruan pemikiran dan gerakan Islam di Indonesia yang intens dalam menegakkan tauhid yang sesungguhnya. Ia dikenal dengan konsep pluralismenya yang mengakomodasi keberagaman/ke-bhinneka-an keyakinan di Indonesia. Menurut Nurcholish Madjid, keyakinan adalah hak primordial setiap manusia dan keyakinan meyakini keberadaan Tuhan adalah keyakinan yang mendasar. Nurcholish Madjid 
mendukung konsep kebebasan dalam beragama, namun bebas dalam konsep Nurcholish Madjid tersebut dimaksudkan sebagai kebebasan dalam menjalankan agama tertentu yang disertai dengan tanggung jawab penuh atas apa yang dipilih. Nurcholish Madjid meyakini bahwa manusia sebagai individu yang paripurna, ketika menghadap Tuhan di kehidupan yang akan datang akan bertanggung jawab atas apa yang ia lakukan, dan kebebasan dalam memilih adalah konsep yang logis. ${ }^{4}$ Dalam artikel ini penulis membatasi bahasan pada konsep tauhidnya yang radikal.Karena alasan ini, penulis menyebutnya sebagai pengusung monotheisme radikal (radical monotheism).

\section{B. Sekilas tentang Nurcholish Madjid}

Fauzan Saleh menyebut Islam yang diusung oleh Nurcholish Madjid sebagai gerakan Islam substansialis, sebagai lawan dari Islam skripturalis. Secara umum, perspektif kaum substansialis dapat dikenali dari empat ide yang menjadi ciri mereka: (1) substansi atau isi keyakinan dan praktik keagamaan lebih penting daripada bentuk. Artinya, mengikuti perintah-perintah al-Quran secara literal kurang bernilai dibandingkan dengan bersikap dan berperilaku moral yang sesuai dengan semangat yang diajarkan al-Quran. (2) Pesan-pesan alQuran dan hadis, meskipun mengandung universal dan abadi, harus ditafsirkan sesuai dengan kondisi sosial setiap generasi umat Islam. (3) Karena tidak mungkin bagi setiap orang untuk mengklaim bahwa dirinya dapat mencapai pemahaman yang mutlak benar tentang kehendak dan perintah-perintah Tuhan, maka umat Islam harus bersikap toleran terhadap sesamanya, dan bahkan terhadap nonMuslim sekalipun. (4) Para pendukung ide ini menerima struktur pemerintahan yang ada saat itu sebagai bentuk yang "sudah final" bagi negara Indonesia, khususnya berkenaan dengan dasar negara dan konstitusinya. ${ }^{5}$ 
Prof. Dr. Nurcholish Madjid atau populer dipanggil Cak Nur, adalahtokoh intelektual yang mencoba untuk men-tauhid-kan manusia modern tersebut. Ia lahir di Jombang, Jawa Timur, 17 Maret 1939. Dia adalah seorang pemikir Islam, cendekiawan, dan budayawan Indonesia.Pada masa mudanya sebagai aktivis Himpunan Mahasiswa Islam (HMI), ide dan gagasannya tentang sekularisasi dan pluralisme pernah menimbulkan kontroversi dan mendapat banyak perhatian dari berbagai kalangan masyarakat.Nurcholish pernah menjabat sebagai Wakil Ketua Dewan Penasehat Ikatan Cendekiawan Muslim Indonesia, dan sebagai Rektor Universitas Paramadina, sampai dengan wafatnya pada tahun 2005.Ia dibesarkan di lingkungan keluarga kiai terpandang di Mojoanyar, Mojokerto, Jawa Timur. Ayahnya, KH Abdul Madjid, dikenal sebagai pendukung Masyumi. ${ }^{6}$

Setelah melewati pendidikan di berbagai pesantren, termasuk Gontor, Ponorogo, menempuh studi kesarjanaan IAIN Jakarta (19611968), tokoh HMI ini menjalani studi doktoralnya di Universitas Chicago, Amerika Serikat (1978-1984), dengan disertasi tentang filsafat dan kalam Ibn Taimiyah. Mengajar di IAIN Syarif Hidayatullah, 1972-1976; dosen pascasarjana IAIN Syarif Hidayatullah, 1985-sekarang; peneliti pada LIPI, 1978-sekarang; guru besar tamu pada Universitas McGill, Montreal, Canada, 1991-1992. Fellow dalam Eisenhower Fellowship, bersama isteri, 1990.Ia banyak menulis makalah-makalah yang diterbitkan dalam berbagai majalah, surat kabar dan buku suntingan, beberapa diantaranya berbahasa Inggris. Buku-bukunya yang telah terbit ialah Khazanah Intelektual Islam (Jakarta, Bulan Bintang/Obor, 1984) dan Islam, Kemodernan dan Keindonesiaan, suntingan Agus Edy Santoso (Bandung, Mizan, 1988).

Sejak 1986, bersama kawan-kawan di ibukota, mendirikan dan memimpin Yayasan Wakaf Paramadina, dengan kegiatan-kegiatan yang mengarah kepada gerakan intelektual Islam di Indonesia.Buku 
ini adalah salah satu hasil kegiatan itu.Dan sejak 1991 menjabat Wakil Ketua Dewan pakar Ikatan Cendekiawan Muslim se-Indonesia (ICMI).

\section{Monotheisme Radikal: Pembebasan Manusia}

Tauhid adalah ajaran yang tidak hanya dibawa oleh Nabi Muhammad saw. semata tetapi nabi-nabi sebelum Muhammad sudah mengajarkan ajaran tauhid. Misi tauhid yang dibawa oleh nabi-nabi terdahulu telah mengalami distorsi yang dilakukan oleh umatnya yang cenderung kepada kepercayaan lokal atau mitosmitos dan tradisi yang disakralkan sehingga menjadi sebuah kepercayaan yang mendistorsi tauhid.

Islam adalah agama yang menganut kepercayaan monoteisme atau tauhid. Sistem kepercayaan ini merupakan lanjutan dari misi tauhid dari agama-agama samawi terdahulu yang juga misi tauhid. Tauhid Islam yang dibawa oleh Muhammad bersifat penyempurna dari ajaran-ajaran tauhid terdahulu, sebagaimana yang telah difirmankan dalam al-Quran yang berbunyi:

Pada hari ini telah Kusempurnakan untukmu agamanu, dan telah Kucukupkan kepadamu nikmat-Ku, dan telah Kuridai Islam itu menjadi agama bagimu. Maka barangsiapa terpaksa karena kelaparan tanpa sengaja berbuat dosa, sesungguhnya Allah Maha Pengampun dan Maha Penyayang (QS. al-Maidah [5]: 3)."

Islam turun di Jazirah Arab yang sebelum datangnya Islam masyarakat pada umumnya menganut sistem kepercayaan politheisme yaitu menyembah banyak dewa. Dewa atau berhala yang mereka sembah tidak sekedar disembah, juga dijadikan tempat untuk menanyakan nasib baik dan buruk. Hubal adalah dewa yang dianggap paling berpengaruh yang membawahi Latta, 'Uzza, Manata, dan yang lainnya. ${ }^{7}$

Selain menganut kepercayaan politheisme tadisi masyarakat Arab menekankan hubungan keusukuan sehingga kesetiaan dan 
solidaritas kelompok menjadi sumber kekuatan bagi kabilah untuk melakukan perang. Oleh karena itu tradisi perang sudah mendarah daging. Dalam masyarakat yang suka berperang nilai wanita menjadi sangat rendah, sehingga anak wanita dianggap sebagai aib bagi keluarga dan tidak banyak anak wanita banyak dibunuh sebelum menikmati manisnya kehidupan. ${ }^{8}$

Meskipun demikian misi tauhid yang dibawa Muhammad untuk melakukan pembebasan bangsa Arab pada khususnya dan bangsa manusia pada umumnya dari praktik kezaliman peradaban. Nilai atau prinsip bagi Nabi tidak menyembah apapun atau siapa pun selain Allah. Prinsip ini merupakan semua sumber kebaikan, kekuatan, kebijaksanaan, pengetahuan, dan rahmat bagi Nabi. Karena efek pembebas dari semangat tauhid adalah pembebasan individu dan pembebasan sosial.

Halangan terberat bagi manusia dalam menerima kebenaran adalah keangkuhan, kesombongan dan kecongkakan yang menjadi belenggu, ia diciptakan oleh manusia sendiri. Belenggu itu adalah "hawa nafsu" atau keinginan sendiri yang menjadi sumber pandangan-pandangan subyektif dan bias dan menghalangi manusia untuk melihat kebenaran. Hal tersebut terjadi karena manusia merasa telah penuh ilmu. Hanya dengan melawan itu semua melalui pembebasan diri seseorang akan mampu menangkap kebenaran, dan hanya dengan kemampuan menangkap kebenaran seseorang dapat melakukan proses untuk pembebasan dirinya. Inilah salah satu pembebasan yang disemangati oleh tauhid.

Gagasan monotheisme radikal (radical monotheism) yang dilekatkan kepada Nurcholish Madjid berangkat dari semangat tauhì $d^{9}$ di atas yang mengandung makna pembebasan, yakni pembebasan dari segala obyek duniawi, moral dan material berupa nilai-nilai dan benda-benda. Jadi sederhananya, menurut Nurcholish Madjid, tauhid yang mengajarkan sikap memahaesakan Tuhan itu memiliki konsekusensi pembebasaan diri dari segala sesuatu yang 
membelenggu selain Tuhan.Tauhid menghendaki pengarahan setiap kegiatan untuk Tuhan dalam upaya mencari ridha-Nya, yang justru merupakan sakralisasi kegiatan manusia. Dengan demikian, sakralisasi mengandung makna pengalihan dari suatu obyek alam ciptaan (makhluk) menuju Tuhan Yang Maha Esa. ${ }^{10}$ Mengenai tauhid tersebut Nurcholish Madjid lebih lanjut menjelaskan,

...Sebenarnya pandangan yang wajar dan apa adanya kepada dunia dan masalahnya, secara otomatis harus dipunyai oleh seorang Muslim, sebagai konsekwensi logis dari tauhid. Pemutlakan transendensi semata-mata kepada Tuhan, sebenarnya, harus melahirkan desaklarisasi pandangan terhadap selain Tuhan, yaitu dunia dan masalah-masalah serta nilai-nilai yang bersangkutan dengannya.Sebab saklarisasi kepada sesuatu selain Tuhan itulah, pada hakikatnya yang dinamakan syirik, lawan tauhid.Maka sekularisasi itu memperoleh maknanya yang konkret, yaitu desaklarisasi terhadap segala sesuatu selain halhal yang benar-benar bersifat Ilahiah (transendental), yaitu dunia ini. ${ }^{11}$

Semangat tauhid tidak hanya berimplikasi sebagai mehamesakan Tuhan saja, tetapi juga memiliki efek pembebesan diri dan pembebasan sosial yang sangat kuat. Efek pembebasan itu sesuai dengan semangat dan fitrah kemanusiaan sebagai ciptaan Tuhan yang paling tinggi, yang karenanya manusia itu harus merdeka sebagaimana disebutkan dalam al-Quran, bahwa manusia harus meletakkan dirinya dalam keimanan, karena dia secara alami dan merupakan sifat bawaan untuk cenderung kepada kebenaran (haniff) karena manusia secara alami adalah lurus. Kecederungan tersebut adalah konsekuensi sifat alami manusia yang telah ditanamkan dalam manusia.Sifat alami kepada kelurusan tak dapat diubah dan bukan merupakan hal yang dapat diubah selamanya, karena merupakan sifat perennial pada manusia. ${ }^{12} \mathrm{Hal}$ ini ditegaskan dalam al-Quran: 
Maka hadapkanlah wajahmu dengan lurus kepada agama (Allah); (tetaplah atas) fitrah Allah yang telah menciptakan manusia menurut fitrah itu.Tidak ada perubahan pada fitrah Allah. (Itulah) agama yang lurus; tetapi kebanyakan manusia tidak mengetahui (QS. al-Rūm [30]: 30).

Perkataan Tauhid dan masalah percaya kepada Tuhan yang Maha Esa menurut Nurcholish Madjid, masih harus dibicarakan kembali, sebab ada kesan bahwa ber-tauhid hanyalah berarti percaya kepada Tuhan.Ternyata jika kita teliti lebih mendalam dan teliti al-Quran, tidaklah sepenuhnya demikian. ${ }^{13}$ Masih ada hal penting yang harus diikuti dari semangat perkataan tauhid itu, yakni menghilangkan paham syirik, paham yang menganggap Tuhan memiliki serikat atau sekutu.Inilah salah satu bentuk semangat tauhid yang belum sepenuhnya mendasari konsekuensi logis paham ke-Tuhan-an.

Nurcholish Madjid mencontohkan hal tersebut dengan orangorang musyrik di Makkah yang dalam al-Quran digambarkan, mereka juga percaya kepada Allah (QS. al-Zumar [39]: 38), namun mereka tidak bisa dikatakan sebagai kaum beriman (al-mu'minūn) dan kaum bertauhid al-muwaḥhidūn), tapi sebaliknya disebut kaum yang mempersekutukan Tuhan atau memperserikatkan Tuhan (almusyrikūn, penganut paham syirik, yakni oknum yang menyertai Tuhan dalam hal keilahian. Padahal merekapun tahu dan sadar betul bahwa sekutu Tuhan itu adalah ciptaan Tuhan juga, bukan Tuhan itu sendiri. ${ }^{14}$ Hal ini digambarkan dalam al-Quran:Dan sungguh jika kamu (Muhammad) bertanya kepada mereka, "Siapakah yang menciptakan mereka (sesama manusia yang mereka sembah selain dari Allah itu?), niscaya mereka menjawab, "Allah", maka bagaimanakah mereka dapat dipalingkan (dari kebenaran)?(QS. alZukhruf [43]: 87).

Tradisi masyarakat Arab seperti yang digambarkan al-Quran di atas memberikan gambaran bahwa, percaya kepada Allah tidak 
dengan sendirinya berarti tauhid.Sebab percaya kepada Allah itu masih ada kemungkinan percaya kepada yang lain-lain sebagai peserta Allah dalam keilahian, Dan inilah problem manusia. Jika manusia tidak melakukan ketundukan dan kepasrahan kepada Tuhan secara mutlak, maka yang terjadi adalah manusia pasti akan tunduk kepada yang relatif. Manusia harus memperkuat ikatan dengan Tuhannya sehingga manusia dapat terbebaskan dari ikatanikatan atau dominasi sesuatu yang derajatnya lebih rendah dari manusia itu sendiri.Yaitu manusia yang sikap tauhidnya belum tercemari oleh nafsu pemujaan terhadap berhala materi. ${ }^{15}$

Dalam pandangan Nurcholish Madjid, problem utama umat manusia ialah politheisme, bukan ateisme, maka program pokok alQuran ialah membebaskan manusia dari belenggu paham Tuhan banyak itu dengan mencanangkan dasar kepercayaan yang diungkapkan dalam kalimat "al-nafy wa al-iśsbat" atau "negasikonformasi" yaitu Lā ilāha illāllāh ${ }^{16}$ yang oleh Marshall Hodgson disebut sebagai "rumusan kepercayaan Muslim"17. Dengan negasi itu dimulai proses pembebesan yaitu pembebasan dari belenggu kepercayaan kepada hal-hal yang palsu. Tetapi demi kesempurnaan kebebasan itu manusia harus mempunyai kepercayaan kepada sesuatu yang benar. Sebab hidup tanpa kepercayaan sama sekali adalah sesuatu yang musthail.

Kalimat Lā ilāha illāllāh merupakan kalimat persaksian. Mengucapkan dan meyakini syahadat adalah bagian dari aqidah, karena merupakan suatu yang fundamental. Kualitas seorang Muslim amat ditentukan oleh kadar kesaksian dan kedalaman pemahamannya terhadap kalimat syahadat itu. Tentunya dengan segala konsekuensi desaklarisasi dari segala bentuk - yang biasa disebut NM dengan tuhan (dengan t kecil) selain Tuhan (dengan T besar) yakni Allah. Dan sesungguhnya inilah tauhid yang benar. Oleh karena itu, manusia pada umumnya yang telah memiliki kepercayan kepada Tuhan, proses pembebasan itu tidak lain dengan melakukan 
DIDIK LUTFI HAKIM: Monotheisme Radikal

pemurnian kepada Tuhan Yang Maha Esa itu sendiri. Pertama melepaskan diri dari kepercayaan kepada sesuatu yang palsu, dan kedua dengan memusatkan kepercayaan hanya kepada yang benar.

Semangat inilah yang sesunguhnya dikandung oleh kalimat syahadat, yang bagaikan suatu gerbang yang secara formal wajib diikrarkan bagi sesorang yang menyatakan diri memeluk Islam. Pernyataan ini sebetulnya bukan sesuatu yang baru dalam diri manusia, melainkan hanya menegaskan, mengingatkan dan mengungkapkan kembali benih monoteisme yang telah tertanam dalam diri manusia dan sesungguhnya merupakan fitrah manusia.Kalimat tersebut (kalimat tauhid) merupakan sekedar penegasan kembali, karena sebelum dilahirkan telah ada perjanjian antara manusia dengan Tuhan yang oleh Lā ilāha illāllāh disebut sebagai perjanjian "primordial" dan karenanya dianggap bagian dari fitrah manusia itu sendiri. ${ }^{18}$

Berpijak dari uraian di atas, Nurcholish Madjid menegaskan bahwa dalam setiap individu terdapat sebuah sikap pembebasan diri dalam memilih keyakinan masing-masing. Atas ketegasan ini, dengan mendasarkan argumentasinya terhadap pernyataan Huston Smith, ${ }^{19}$ ia menyatakan bahwa keengganan manusia untuk menerima kebebasan ialah antara lain karena sikap menutup diri yang timbul dari reflex agnostic atau keengganan untuk tahu tentang kebenaran yang diperkirakan justru akan lebih tinggi nilainya daripada apa yang sudah ada pada diri dan keyakinannya. Padahal, kata Smith, kalau saja setiap individu membuka diri untuk menerima kebenaran di luar keyakinannya, maka mungkin saja akan mendapatkan kebaikan dan energi yang diperlukan. ${ }^{20}$

Tuhan memberikan akal agar dengannya manusia dapat berfikir dan mendapatkan petunjuk dalam mengarungi bahtera kehidupan. Akal dalam perspektif Islam menempati posisi yang sangat terhormat, karena dengan akal tersebut Tuhan memberikan beban hukum kepada manusia.Islam mengharamkan segala sesuatu 
yang dapat menghalangi eksistensi akal manusia.Karena sesungguhnya Islam menginginkan agar manusia selalu berfikir dan menggunakan akalnya demi kelangsungan kehidupan sesuai dengan jalan yang telah digariskan Tuhan.Dalam kenyataan inilah Nurcholish Madjid menegaskan bahwa setiap pribadi manusia adalah berharga, seharga kemanusiaan sejagad. Barangsiapa merugikan seorang pribadi, seperti membunuhnya, tanpa alasan yang sah, maka ia bagaikan merugikan seluruh umat manusia, dan barangsiapa berbuat baik kepada seseorang, seperti menolong hidupnya, maka ia bagaikan berbuat baik kepada seluruh umat manusia. $^{21}$

Salah satu kelanjutan logis dari prinsip keesaan Tuhan itu ialah persamaan manusia. Yakni, semua manusia dilihat dari derajatnya, harkatnya, dan martabatnya adalah sama. Tak seorang pun dapat merendahkan atau menjatuhkan derajat, harkat, dan martabat sesama manusia, misalnya dengan memaksakan sesuatu yang ia anggap benar kepada orang lain. Karena keesaan Tuhan adalah kemutlakannya.Ketiadaan sesuatu yang memiliki kebenaran mutlak selain diri-Nya meniscayakan kebenaran yang relatif bagi seluruh makhluknya.

Dari prinsip-prinsip tauhid di atas setiap manusia memiliki hak penuh untuk kebebasan pribadinya dan menentukan kebenarannya tanpa 'intimidasi' dari manusia lain. Dengan kebebasan pribadinya, manusia berhak menentukan secara sadar dan bertanggung jawab atas pilihannya yang baik dan yang buruk. Tuhan pun sepenuhnya memberikan kebebasan kepada setiap manusia untuk menentukan pilihannya untuk menerima atau menolak petunjuk-Nya, tentunya dengan risiko yang akan ditanggung oleh manusia itu sendiri berdasarkan pilihannya. Madjid lebih jauh menulis:

Maka sebagai makhluk tertinggi, manusia harus "melihat ke atas" hanya kepada Tuhan, kemudian kepada sesamanya harus melihat dalam garis mendatar yang rata, dan kepada alam harus 
melihat ke bawah, dalam arti melihatnya dengan kesadaran bahwa dalam hierarki ciptaan Tuhan, alam adalah lebih rendah daripada dirinya. Dari sudut pandang ini dapat dipahami logika syirik, yaitu sikap mempersekutukan Allah dengan memuja alam atau memandang alam secara lebih dari semestinya, sebagai dosa terbesar. Yaitu, karena syirik merupakan tindakan manusia mengingkari anugerah ketinggian harkat dan martabatnya sebagai puncak ciptaan.Maka kemusyrikan dengan sendirinya berarti kekafiran. ${ }^{22}$

Menurut Nurcholish Madjid, karena kemahaesaan-Nya dan kemutlakan-Nya, wujud Tuhan adalah wujud kepastian. Justru Tuhanlah satu-satunya wujud yang pasti.Semua selain Tuhan adalah wujud yang tidak pasti, yang nisbi belaka.Termasuk manusia sendiri, betapa pun tingginya kedudukan manusia sebagai puncak ciptaan Tuhan. ${ }^{23}$ Melalui pernyataan ini, Madjid ingin menegaskan bahwa sikap memutlakkan nilai manusia, baik yang dilakukan oleh seseorang kepada dirinya sendiri maupun kepada orang lain, adalah bertentangan dengan prinsip Ketuhanan Yang Maha Esa, atau tauhīd, monotheisme.Beribadat yang tulus kepada Tuhan tidak bisa terjadi dalam satu pribadi dengan sikap memutlakkan sesama makhluk, termasuk manusia. Makhluk, pada umumnya, dan manusia, pada khususnya, yang mengalami pemutlakan itu, disebut țāghūt, yang berarti tiran, dan makhluk atau orang itu akan menjelma menjadi nidd (jamak: andad, saingan Tuhan atau tuhan-tuhan palsu). ${ }^{24}$ Sekali lagi, Madjid menggarisbawahi konsep tauhidnya sebagai berikut:

Maka setiap bentuk pengaturan hidup sosial manusia yang melahirkan kekuasaan mutlak, adalah bertentangan dengan jiwa Tauhid, Ketuhanan Yang Maha Esa, atau Monotheisme. Pengaturan hidup dengan menciptakan kekuasaan mutlak pada sesama manusia adalah tidak adil dan tidak beradab. Sikap yang pasrah kepada Tuhan, yang memutlakkan Tuhan dan tidak sesuatu yang lain, menghendaki tatanan sosial terbuka, adil, dan demokratis. Inilah yang telah dicontohkan oleh Nabi Muhammad 
s.a.w. yang keteladanannya diteruskan kepada para khalifah yang bijaksana sesudahnya. 25

Implikasi dari konsep tauhid yang digagas oleh Nurcholish Madjid di atas melahirkan aspek-aspek penting dalam kehidupan sosial manusia.Pertama, paham persamaan manusia. Yakni bahwa seluruh umat manusia, dari segi harkat dan martabat asasinya adalah sama. Tidak seorang pun dari sesama manusia berhak merendahkan atau menguasai harkat dan martabat manusia lain, misalnya dengan memaksanakan kehendak dan pandangannya kepada orang lain. Bahkan seorang utusan Tuhan pun tidak berhak melakukan pemaksaan itu.Seorang utusan Tuhan mendapat tugas hanya untuk menyampaikan kebenaran (balaghah, tabligh) kepada umat manusia, bukan untuk memaksakan kebenaran kepada mereka. ${ }^{26}$ Kedua, setiap manusia mengasumsikan kebebasan diri pribadinya.Dengan kebebasan itu manusia menjadi makhluk moral, yakni makhluk yang bertanggung jawab sepenuhnya atas segala perbuatan yang dipilihnya dengan sadar, yang saleh maupun yang jahat.Tuhan pun tetap memberi kebebasan kepada manusia untuk menerima atau menolak petunjuk-Nya, dengan risiko yang harus ditanggung manusia sendiri sesuai dengan pilihannya itu.Justru manusia mengada melalui dan di dalam kegiatan amalnya. Dalam amal itulah manusia mendapatkan eksistensi dan esensi dirinya, dan di dalam amal yang ikhlas manusia menemukan tujuan penciptaan dirinya, yaitu kebahagiaan karena "pertemuan" (liqā) dengan Tuhan, dengan mendapatkan rida-Nya. ${ }^{27}$

Ketiga, setiap orang dituntut rendah hati.Sikap ini muncul karena manusia tidak mungkin mengetahui Kebenaran Mutlak. Pengetahuan manusia itu betapa pun tingginya, tetap terbatas.Di sinilah manusia perlu kerendahanhati dengan menginsafi dan memastikan diri bahwa manusia senantiasa ada Dia Yang Maha Tahu, yang mengatasi setiap orang yang tahu.Karena itu, manusia dituntut untuk bisa saling mendengar sesamanya, dan mengikuti 
mana saja dari banyak pandangan manusiawi itu paling baik. "Dengan begitu Tauhid menghasilkan bentuk hubungan kemasyarakatan manusia yang menumbuhkan kebebasan menyatakan pikiran dan kesediaan mendengar pendapat, sehingga terjadi pula hubungan saling mengingatkan akan apa yang benar dan baik, serta keharusan mewujudkan yang benar dan baik itu dengan tabah dan sabar. ${ }^{28}$

\section{E. Penutup}

Dari uraian di atas jelaslah bahwa inti dari monotheisme radikal Nurcholish Madjid adalah membebaskan manusia dari terikat kepada apa pun selain Tuhan, dan selanjutnya memfokuskan seluruh fikiran dan amal perbuatan hanya kepada Tuhan. Jika ini sudah dipegangi dengan kuat, manusia akan terbebas dari belenggu yang dibuat oleh manusia, dan ia tidak lagi takut kepada siapa pun kecuali hanya kepada-Nya. Implikasi dari ini adalah tidak boleh ada bentuk penjajahan dari suatu kelompok manusia atas manusia yang lain. [

\section{Catatan Akhir}

${ }^{1}$ M. Natsir, Fiqh Da'wah, Solo: Ramadhani, 1987, h. 39; Sulaiman Al-Kumayi, Kearifan Spiritual: Dari Hamka ke Aa Gym, Semarang: Pustaka Nuun, 2004, h. 49.

2Hamka, Pelajaran Agama Islam, Jakarta: Bulan Bintang, 1992, h. 182.

${ }^{3}$ Maulana Muhammad Ali, The Holy Qur'an: Arabic Text, English Translation and Commentary, Lahore, U.S.A.: Ahmadiyah Anjuman Isha'at Islam, 1991, h. 89.

${ }^{4}$ Greg Barton, Gagasan Islam Liberal di Indonesia: Pemikiran Neomodernisme Nurcholish Madjid, Djohan Effendi, Ahmad Wahib, dan Abdurrahman Wahid, terj. Nanang Tahqiq, Jakarta: Paramadina, 1999, h. 74 .

${ }^{5}$ Fauzan Saleh, Teologi Pembaruan: Pergeseran Wacana Islam Sunni di Indonesia Abad XX, Jakarta: Serambi, 2004, h. 333-334. 
6Muryanto, Tauhid dan Pembebasan Bangsa: Telaah Sosiologis atas Pemikiran Tauhid Prof. Dr. Nurcholish Madjid, Skripsi S1 Fakultas Ushuluddin IAIN Walisongo, 2003, h. 1.

7Badri Yatim, Sejarah Peradaban Islam, Jakarta: Raja Grafindo, 1999, h. 15.

8Ibid., h. 11.

${ }^{9}$ Nurcholish Madjid, Islam Doktrin dan Peradaban, Jakarta: Paramadina, 1992, h.72.

${ }^{10}$ Nurcholish Madjid, "Sekitar Usaha Membangkitkan Etos Intelektualisme Islam Indonesia", dalam Endang Syaefuddin Anshari (ed.), 70 Tahun Prof. HM. Rasyidi, Jakarta: Pelita, 1985, h. 216.

${ }^{11}$ Nurcholish Madjid, Islam, Kemodernan dan Keindonesiaan, Bandung: Mizan, 1998, h. 208.

${ }^{12}$ Nurcholis Madjid dkk, Islam dan Humanisme, Artikulasi Humanisme Islam di Tengah Krisis Humanisme Universal, Yogyakarta:Pustaka Pelajar, 2007, h. 23-24.

${ }^{13}$ Nurcholis Madjid, Islam Doktrin, h. 74

${ }^{14}$ Ibid., h. 75

${ }^{15}$ Komaruddin Hidayat dan M. Wahyudi Nafis, Agama Masa Depan: Perspektif Filsafat Perennial, Jakarta: Paramadina, 2003, h. 61.

${ }^{16}$ Nurcholis, Islam Doktrin, h. 78.

${ }_{17}$ Marshall G. S. Hodgson, The Venture of Islam, Consciense and History in a World Civilization, Jil. I. Diterjemahkan oleh Mulyadhi Kartanegara dengan judul The Venture of Islam, Iman dan Sejarah Dalam Peradaban Dunia, Jakarta: Paramadina, 2002, h. 115.

${ }_{18}$ M. Asrul Pattimahu, "Nurcholish Madjid dan Pembaruan Islam: Pemikiran Nurcholish Madjid tentang Modernisasi Sekularisasi dan Desakralisasi",

http://rullyasrul83.wordpress.com/2009/07/29/9/(diakses, 2 Mei 2014).

${ }^{19}$ Huston Smith, Agama-agama Manusia, Jakarta: YOI, 2001.

${ }^{20}$ Nurcholish Madjid, Islam Doktrin, h. 81.

${ }^{21}$ Nurcholish Madjid, Masyarakat Religius, Jakarta: Paramadina, 1997, h. 39.

${ }^{22}$ Dikutip dari Mohammad Monib dan Islah Bahrawi, Islam dan Hak Asasi Manusia Dalam Pandangan Nurcholish Madjid, Jakarta: Gramedia, 2011, h. 78; sumber asli: Nurcholish Madjid, Cita-cita Politik Islam Era Reformasi, Jakarta: Paramadina, 1999, h. 230.

${ }^{23}$ Nurcholish Madjid, Islam Doktrin, h. 3.

TEOLOGIA, VOLUME 25, NOMOR 2, JULI-DESEMBER 2014 
24Ibid., h. 3.

25Ibid.,h. 3-4.

26Ibid., h. 4.

27Ibid., h. 4.

28Ibid., h. 4-5. 


\section{DAFTAR PUSTAKA}

Barton, Barton, Gagasan Islam Liberal di Indonesia: Pemikiran Neomodernisme Nurcholish Madjid, Djohan Effendi, Ahmad Wahib, dan Abdurrahman Wahid, terj. Nanang Tahqiq, Jakarta: Paramadina, 1999.

Hidayat, Komaruddin, dan M. Wahyudi Nafis, Agama Masa Depan, Perspektif Filsafat Perennial, Jakarta: Paramadina, 2003).

Hodgson, Marshall G. S.,The Venture of Islam, Consciense and History in a World Civilization, Jilid I. Diterjemahkan oleh Mulyadhi Kartanegara dengan judul The Venture of Islam, Iman dan Sejarah Dalam Peradaban Dunia, (Jakarta, Paramadina; Agustus 2002.

Madjid, Nurcholish dkk, Islam dan Humanisme, Artikulasi Humanisme Islam di Tengah Krisis Humanisme Universal, (Cet;I, Yogyakarta: Pustaka Pelajar, 2007.

Madjid, Nurcholish, "Sekitar Usaha Membangkitkan Etos Intelektualisme Islam Indonesia", dalam Endang Syaefuddin Anshari (ed.), 70 Tahun Prof. HM. Rasyidi, Jakarta: Pelita, 1985.

Madjid, Nurcholish, Islam Doktrin dan Peradaban, Jakarta: Paramadina, 1992.

Madjid, Nurcholish, Islam, Kemodernan dan Keindonesiaan, Bandung: Mizan, 1998.

Madjid, Nurcholish, Masyarakat Religius, Jakarta: Paramadina, 1997.

Madjid, Nurcholish, Cita-cita Politik Islam Era Reformasi, Jakarta: Paramadina, 1999.

Monib, Mohammad, dan Islah Bahrawi, Islam dan Hak Asasi Manusia Dalam Pandangan Nurcholish Madjid, Jakarta: Gramedia, 2011.

Muryanto, Tauhid dan Pembebasan Bangsa: Telaah Sosiologis atas Pemikiran Tauhid Prof. Dr. Nurcholish Madjid, Skripsi S1 Fakultas Ushuluddin IAIN Walisongo, 2003. 
Nashir, Haedar, Agama dan Krisis Kemanusiaan Modern, Yogyakarta: Pustaka Pelajar, 1997.

Pattimahu, M. Asrul, "Nurcholish Madjid dan Pembaruan Islam: Pemikiran Nurcholish Madjid tentang Modernisasi Sekularisasi dan Desakralisasi", http://rullyasrul83.wordpress.com/ 2009/07/ 29/9/ (diakses, 2 Mei 2014).

Smith, Histon, Agama-agama Manusia, Jakarta: YOI, 2001.

Yatim, Badri, Sejarah Peradaban Islam, Jakarta: Raja Grafindo, 1999. 